\title{
Catalytic Conversion of Light Hydrocarbons into Aromatic Hydrocarbons over Modified Zeolite Catalysts
}

\author{
BALGA TUKTIEVICH TUKTIN ${ }^{1 *}$, NURZHAN NURLYBEKOVICH NURGALIYEV ${ }^{1,2}$ \\ ALIYA SERIKOVNA TENIZBAYEVA ${ }^{1}$ and ANATOLIY ALEXSANDROVICH SHAPOVALOV ${ }^{1}$ \\ 'D.V. Sokolsky Institute of Fuel, Catalysis and Electrochemistry, Almaty, Republic of Kazakhstan. \\ 1,2 School of Chemical Engineering, Kazakh-British Technical University, \\ Almaty, Republic of Kazakhstan. \\ ${ }^{*}$ Corresponding author E-mail: tuktin_balga@mail.ru \\ http://dx.doi.org/10.13005/ojc/330424
}

(Received: June 09, 2017; Accepted: July 14, 2017)

\begin{abstract}
The process of conversion of light alkanes into aromatic hydrocarbons on zeolite catalysts, modified with $\mathrm{Zn}, \mathrm{La}, \mathrm{Fe}$ and $\mathrm{Zr}$ was investigated in this work. The catalysts were tested in the conversion process of propane-butane and propane-propylene mixtures at atmospheric pressure, variation of temperature and space velocity (SV). It is observed that the maximum amount of aromatic hydrocarbons (34.6\%) are formed in the conversion of propane-butane mixture over Zn-La-Fe-ZSM$\mathrm{Al}_{2} \mathrm{O}_{3}$ catalyst at $550{ }^{\circ} \mathrm{C}$, selectivity to aromatic hydrocarbons is $39,2 \%$.
\end{abstract}

Keywords: propane-propylene, propane-butane, zeolite-containing catalyst, aromatic hydrocarbon.

\section{INTRODUCTION}

Aromatic hydrocarbon are important starting materials in basic organic synthesis. They are used for manufacturing plastics, synthetic fibers, resins, various-purpose rubbers, dyes, surfactants and pharmaceutical and agricultural products. Rational use of light hydrocarbons that are component of natural, associated and refinery gases, is an actual problem. $\mathrm{C}_{1}-\mathrm{C}_{4}$ hydrocarbons contained in these gases can be converted into aromatic hydrocarbons over zeolite catalysts. Aromatic hydrocarbons are an important feedstock for many petrochemical processes. However, so far a significant part of the light hydrocarbon are used as technological and household fuel or flared on torches, causing considerable damage to the environment. Today zeolite-containing catalysts, especially high-silica zeolites such as pentasil are widely used in the petrochemical and refining industries due to unique microporous structure and acid-base properties, capable of converting light hydrocarbons into valuable products of petrochemical synthesis. Researches of catalytic conversions of light hydrocarbon are conducted in many countries of the world. At the same time the direction of recycling process and the yield of products, generally depend on nature, conditions 
of preparation of the catalyst and carrying out the process. Catalytic conversions of light hydrocarbon into aromatic hydrocarbons are intensively studied on the modified pentasil-contained catalysts ${ }^{1-13}$.

\section{MATERIALS AND METHODS}

Modified zeolite-containing catalysts: $\mathrm{Zn}-\mathrm{La}-\mathrm{Zr}-\mathrm{ZSM}-\mathrm{Al}_{2} \mathrm{O}_{3}$, Zn-La-Co-ZSM-AI $\mathrm{O}_{3}$, $\mathrm{Zn}$-La-Fe-ZSM- $\mathrm{Al}_{2} \mathrm{O}_{3}$ were prepared by impregnation of mixture of aluminum hydroxide and HZSM-5 zeolite with aqueous solutions of metal salts with subsequent drying at $150{ }^{\circ} \mathrm{C}$ and calcinating at $550^{\circ} \mathrm{C}$. The synthesized catalysts were tested in the conversion process of propane-butane and propanepropylene mixture in a flow-type quartz reactor with a fixed-bed catalyst at atmospheric pressure, and variation of the reaction temperature from 450 to $600{ }^{\circ} \mathrm{C}$, SV from 140 to $500 \mathrm{hr}^{-1}$. The flow -type reactor contained $5 \mathrm{~g}$ of the catalyst with particle size of 1-2 mm sandwiched between quartz grit layers. The reaction products were cooled in receiver with a consender plased in special immersion cooler to collect the liquid fraction.

The reaction products were analyzed by chromatographic (GLC) method on the equipment "Chrom-5"with the column filled with alumina of "Supelco" firm. Liquid organic products were determined by GLS "Agilent 6890" with the capillary column $60 \mathrm{~m} \times 0.250 \mathrm{~mm}$. Liquid aromatic hydrocarbons and gaseous products are formed during the conversion of propane-butane mixture. Benzene, toluene, ethylbenzene, xylenes and the $\mathrm{C}_{8+}$ hydrocarbons were found in the liquid products. $\mathrm{C}_{1}-\mathrm{C}_{4}$ hydrocarbons are present in the gaseous products of reaction.

Physical and chemical characteristics of the synthesized catalysts were studied. The specific surface area and porosity of the catalysts have been measured by Brunauer-Emmett - Teller (BET) method on low-temperature adsorption of nitrogen. The acid characteristics of the catalysts were investigated by temperature-programmed desorption of ammonia ${ }^{14}$.

\section{RESULTS AND DISCUSSION}

The conversion of the propane-butane mixture on a $\mathrm{Zn}-\mathrm{La}-\mathrm{Zr}-\mathrm{ZSM}-\mathrm{Al}_{2} \mathrm{O}_{3}$ catalyst was studied at a space velocity $350 \mathrm{hr}^{-1}$ (Table 1). With an increase in temperature from 450 to $600^{i} \tilde{N}$ the conversion of hydrocarbons $(X)$ rises from 35.1 to $88.3 \%$. The yield of aromatic hydrocarbons $(Y)$ in these conditions increases from 12.3 to $24.2 \%$.

In the process of conversion the propanebutane mixture liquid aromatic hydrocarbons and gaseous products are formed. In the liquid products benzene, toluene, ethylbenzene, xylenes and $\mathrm{C}_{8+}$ hydrocarbons were found. In gaseous reaction products, there are $\mathrm{C}_{1}-\mathrm{C}_{4}$ hydrocarbons.

An increase in temperature of the reaction increases from 400 to $600{ }^{\circ} \mathrm{C}$ results in the growth of benzene yield from 18.9 to $38.5 \%$ where as the yields of ethylbenzene and xylene are reduced from 17.8 to $7.5 \%$ and from 5.8 to $2.4 \%$, respectively. The maximum yield of toluene is $62.1 \%$ at $500^{\circ} \mathrm{C}$, with further growth of temperature this value decreases to $50.0 \%\left(600^{\circ} \mathrm{C}\right)$.

An increase in temperature leads in increased cracking with formation of $\mathrm{C}_{1}-\mathrm{C}_{2}$ hydrocarbons. The yield of methane grows from $1.2 \%$ to $47.5 \%$, the yield of ethane increases from $1.4 \%$ to $52.5 \%$ with temperature rise.

Conversion of propane-butane fraction over the $\mathrm{Zn}$-La-Co-ZSM-Al $\mathrm{O}_{3}$ catalyst are shown in Table 2, an increase in temperature from 450 to

Table 1: Conversion of propane-butane mixture over the $\mathrm{Zn}-\mathrm{La}-\mathrm{Zr}-\mathrm{Al}_{2} \mathrm{O}_{3}$ catalyst

\begin{tabular}{llllllll}
\hline \multirow{2}{*}{${ }^{0} \boldsymbol{C} C$} & $\boldsymbol{X}, \%$ & $\boldsymbol{Y}, \%$ & \multicolumn{5}{c}{ Composition of products, \% } \\
\cline { 3 - 7 } & & & Benzene & Toluene & Ethylbenzene & Xylenes $^{*} \mathbf{C}_{8+}$ \\
\hline 450 & 35.1 & 12.3 & 18.9 & 56.3 & 17.8 & 5.8 & 1.2 \\
500 & 63.1 & 21.3 & 20.9 & 62.1 & 10.2 & 5.3 & 1.5 \\
550 & 77.4 & 25.0 & 29.5 & 54.4 & 9.7 & 4.6 & 1.8 \\
600 & 88.3 & 24.2 & 38.5 & 50.0 & 7.5 & 2.4 & 1.6 \\
\hline
\end{tabular}


$600{ }^{\circ} \mathrm{C}$ leads to raise of conversion degree from $60.2 \%$ to $98.4 \%$. The yield of aromatic hydrocarbons passes through a maximum $(31.4 \%)$ at $550{ }^{\circ} \mathrm{C}$. The selectivity to aromatic hydrocarbons decreases from $37.0\left(450{ }^{\circ} \mathrm{C}\right)$ to $24.5 \%\left(600^{\circ} \mathrm{C}\right)$. With increase in temperature from 450 to $600^{\circ} \mathrm{C}$ the quantity of benzene in a liquid product increases from 16.0 to $49.2 \%$, toluene decreases from 64.6 to $47.2 \%$, ethylbenzene from 13.9 to $2.7 \%$ and xylenes from 3.8 to $0.9 \%$. Cracking of hydrocarbons increases with formation of methane and ethane as the temperature grows from 450 to $600^{\circ} \mathrm{C}$. The yield of methane and ethane increases from 8.3 to $28.0 \%$ and from 2.3 to $42.0 \%$, respectively.
The highest yield of aromatic hydrocarbons (34.6\%) during conversion of propane-butane mixture is observed over the zeolite-containing catalyst $\mathrm{Zn}-\mathrm{La}-\mathrm{Fe}-\mathrm{ZSM}-\mathrm{Al}_{2} \mathrm{O}_{3}$ modified with zinc, iron, lanthanum (Table 3). The maximum selectivity to the yield of aromatic hydrocarbons is $39.2 \%$ at $550{ }^{\circ} \mathrm{C}$. As the reaction temperature grows in the range of $450-600{ }^{\circ} \mathrm{C}$ the degree of conversion increases from $75.4 \%$ to $90.2 \%$. There were observed changes in the composition of liquid products. Thus, as process temperature increases the amount of benzene goes up from 12.7 to $44.1 \%$, the yield of toluene and ethylbenzene decreases from 61.6 to $47.7 \%$ and from 16.7 to $5.7 \%$, respectively.

Table 2: Conversion of propane-butane mixture over the $\mathrm{Zn}-\mathrm{La}-\mathrm{Co}-\mathrm{ZSM}-\mathrm{Al}_{2} \mathrm{O}_{3}$ catalyst at SV=350 $\mathrm{hr}^{-1}$

\begin{tabular}{|c|c|c|c|c|c|c|c|}
\hline \multirow[t]{2}{*}{$T_{,}^{o} \mathrm{C}$} & \multirow[t]{2}{*}{$X, \%$} & \multirow[t]{2}{*}{$Y, \%$} & \multicolumn{4}{|c|}{ Composition of products, $\%$} & \multirow[b]{2}{*}{$\mathrm{C}_{8+}$} \\
\hline & & & Benzene & Toluene & Ethylbenzene & Xylenes & \\
\hline 450 & 60.2 & 22.3 & 16.0 & 64.6 & 13.9 & 3.8 & 1.7 \\
\hline 500 & 81.3 & 28.4 & 35.8 & 51.7 & 9.3 & 2.7 & 0.5 \\
\hline 550 & 92.6 & 31.4 & 41.3 & 52.0 & 5.1 & 1.6 & - \\
\hline 600 & 98.4 & 24.1 & 49.2 & 47.2 & 2.7 & 0.9 & - \\
\hline \multicolumn{8}{|c|}{$\begin{array}{l}\text { Table 3: Conversion of propane-butane mixture over the } \mathrm{Zn} \text {-La-Fe-ZSM- } \mathrm{Al}_{2} \mathrm{O}_{3} \\
\text { catalyst at } \mathrm{SV}=350 \mathrm{hr}^{-1}\end{array}$} \\
\hline \multirow[t]{2}{*}{$\mathrm{T}^{\circ} \mathrm{C}$} & $X, \%$ & $Y, \%$ & \multicolumn{4}{|c|}{ Composition of products, $\%$} & \\
\hline & & & Benzene & Toluene & Ethylbenzene & Xylenes & $\mathrm{C}_{8+}$ \\
\hline 450 & 75.4 & 28.4 & 12.7 & 61.6 & 16.7 & 6.9 & 2.1 \\
\hline 500 & 83.5 & 31.4 & 30.7 & 45.9 & 14.9 & 5.6 & 2.9 \\
\hline 550 & 88.3 & 34.6 & 40.7 & 47.0 & 8.4 & 3.3 & 0.6 \\
\hline 600 & 90.2 & 28.1 & 44.1 & 47.7 & 5.7 & 2.5 & - \\
\hline
\end{tabular}

Table 4: Stability testing of the modified zeolite-containing $\mathrm{Zn}$-La-Fe-ZSM- $\mathrm{Al}_{2} \mathrm{O}_{3}$ catalyst in conversion of propane-butane mixture at $550^{\circ} \mathrm{C}, \mathrm{SV}=370 \mathrm{hr}^{-1}$

\begin{tabular}{lllllll}
\hline $\begin{array}{l}\text { Catalyst running } \\
\text { time, hr. }\end{array}$ & $\boldsymbol{X}, \%$ & $\boldsymbol{Y}, \%$ & \multicolumn{3}{l}{ Composition of products, \% } \\
\cline { 3 - 7 } & & & Benzene & Toluene & Ethylbenzene & Xylenes \\
\hline 1 & 81.1 & 30.9 & 36.6 & 43.8 & 15.5 & 4.1 \\
2 & 78.9 & 32.5 & 33.0 & 45.5 & 14.2 & 7.3 \\
3 & 79.0 & 31.5 & 31.6 & 45.9 & 14.5 & 8.0 \\
5 & 80.2 & 30.0 & 32.7 & 47.0 & 12.5 & 7.8 \\
7 & 81.2 & 32.0 & 32.2 & 46.0 & 13.8 & 8.0 \\
\hline
\end{tabular}


The influence of the SV $(140,350,450$, $500 \mathrm{hr}^{-1}$ ) on the degree of conversion and the yield of products over the catalyst $\mathrm{Zn}-\mathrm{La}-\mathrm{Fe}-\mathrm{ZSM}-\mathrm{Al}_{2} \mathrm{O}_{3}$ at $550^{\circ} \mathrm{C}$ has been studied. With the increase SV of propane-butane mixture from 140 to $500 \mathrm{hr}^{-1}$, a decrease occurs in the yield of aromatic hydrocarbons from 49.1 to $20.7 \%$ and the degree of conversion from 88.7 to $75.8 \%$, which connected with the reduction of time of contact of active centers of the catalyst with a feed.

With increase of feed rate from 140 to $500 \mathrm{hr}^{-1}$ the yields of benzene and xylenes are reduced from 31.7 to $19.3 \%$ and from 8.8 to $2.3 \%$, respectively the yield of toluene increases from 38.7 to $70.8 \%$ and ethylbenzene passes through a maximum at $350 \mathrm{hr}^{-1}$. Cracking is limited as the SV grows, the yields of methane and ethane are decreased from 21.1 to $4.2 \%$ and from 29.2 to $16.6 \%$, respectively.

Stability of the $\mathrm{Zn}-\mathrm{La}-\mathrm{Fe}-\mathrm{ZSM}-\mathrm{Al}_{2} \mathrm{O}_{3}$ catalyst was studied at conversion of propane-butane mixture (Table 4). It was observed that continuous work of the catalyst from 1 to $7 \mathrm{~h}$ the yield of aromatic hydrocarbons (30.0-32.5\%) and the degree of conversion (81.0-78.9\%) change slightly. The selectivity to the yield of aromatic hydrocarbons fluctuates within $37.4-41.2 \%$. The qualitative composition of the liquid products remains practically unchanged. Toluene (47.0\%) and benzene (36.6\%) are formed in the prevailing quantity.

It should be noted that the cracking of hydrocarbons proceeds less intensively over the catalyst $\mathrm{Zn}-\mathrm{La}-\mathrm{Fe}-\mathrm{ZSM}-\mathrm{Al}_{2} \mathrm{O}_{3}$ than over the catalysts

Table 5: Conversion of propane-propylene mixture over the $\mathrm{Zn}-\mathrm{La}-\mathrm{Fe}-\mathrm{ZSM}-\mathrm{Al}_{2} \mathrm{O}_{3}$ catalyst at SV $=350 \mathrm{hr}^{-1}$

\begin{tabular}{lllllll}
\hline \multirow{2}{*}{${ }^{\circ} \boldsymbol{C}$} & $\boldsymbol{X}, \%$ & $\boldsymbol{Y}, \%$ & \multicolumn{4}{c}{ Composition of products, \% } \\
\cline { 4 - 6 } & & & Benzene & Toluene & Ethylbenzene & Xylenes \\
\hline 450 & 61.8 & 35.2 & 24.8 & 53.7 & 16.3 & 5.2 \\
500 & 72.9 & 35.8 & 39.1 & 46.9 & 10.9 & 3.1 \\
550 & 88.4 & 38.4 & 40.4 & 49.1 & 8.1 & 6.0 \\
600 & 100.0 & 33.9 & 55.1 & 37.8 & 6.0 & 1.1 \\
\hline
\end{tabular}

Table 6: Specific surface area and porosity of the catalysts

\begin{tabular}{llll}
\hline Catalyst & $\begin{array}{l}\text { Specific surface } \\
\text { area, } \mathbf{~ m}^{2} / \mathbf{g}\end{array}$ & $\begin{array}{l}\text { Pore volume, } \\
\mathbf{m l} / \mathbf{g}\end{array}$ & $\begin{array}{l}\text { Pore size, } \\
\mathbf{n m}\end{array}$ \\
\hline $\mathrm{Zn}-\mathrm{La}-\mathrm{Fe}-\mathrm{ZSM}-\mathrm{Al}_{2} \mathrm{O}_{3}$ & 283.0 & 0.25 & 1.5 \\
$\mathrm{Zn}-\mathrm{La}-\mathrm{Co}-\mathrm{ZSM}-\mathrm{Al}_{2} \mathrm{O}_{3}$ & 289.7 & 0.24 & $1.5 ; 3.0$ \\
$\mathrm{Zn}-\mathrm{La}-\mathrm{Zr}-\mathrm{ZSM}_{2} \mathrm{Al}_{2} \mathrm{O}_{3}$ & 310.7 & 0.24 & 2.0 \\
\hline
\end{tabular}

Table 7: Temperature-programmed desorption of ammonia

\begin{tabular}{|c|c|c|c|c|c|c|c|}
\hline \multirow[t]{2}{*}{ Catalysts } & \multicolumn{2}{|c|}{$\mathbf{T}_{\max },{ }^{\circ} \mathbf{C}$} & \multicolumn{4}{|c|}{$\begin{array}{l}\text { The quantity of desorbed } \\
\text { ammonia, } 10^{-4} \mathrm{~mol} / \mathrm{g} \text { of catalyst }\end{array}$} & \multirow[t]{2}{*}{$\begin{array}{l}\mathrm{\Sigma NH}_{3^{.}}, 10^{-4} \mathrm{~mol} / \mathrm{g} \\
\text { of cat. }\end{array}$} \\
\hline & 1 & 2 & 3 & 1 & 2 & 3 & \\
\hline $\mathrm{Zn}$-La-Fe-ZSM-Al $\mathrm{O}_{3}$ & 115 & 320 & 470 & 22.60 & 7.80 & 4.80 & 35.20 \\
\hline $\mathrm{Zn}$-La-Co-ZSM-AI ${ }_{2} \mathrm{O}_{3}$ & 152 & 310 & 480 & 23.70 & 8.80 & 4.0 & 36.50 \\
\hline $\mathrm{Zn}-\mathrm{La}-\mathrm{Zr}-\mathrm{ZSM}-\mathrm{Al}_{2} \mathrm{O}_{3}$ & 175 & - & 490 & 24.0 & - & 9.4 & 33.4 \\
\hline
\end{tabular}


$\mathrm{Zn}-\mathrm{La}-\mathrm{Zr}-\mathrm{Al}_{2} \mathrm{O}_{3}$ and $\mathrm{Zn}$-La-Co-ZSM- $\mathrm{Al}_{2} \mathrm{O}_{3}$. During conversion propane-butane mixture over the $\mathrm{Zn}$-La$\mathrm{Fe}-\mathrm{ZSM}-\mathrm{Al}_{2} \mathrm{O}_{3}$ catalyst as the temperature increases from 400 to $600^{\circ} \mathrm{C}$, the yield of methane grows from $9.0 \%$ to $19.1 \%$ and the yield of ethane increases from $17.7 \%$ to $25.8 \%$.

The $\mathrm{Zn}$-La-Fe-ZSM- $\mathrm{Al}_{2} \mathrm{O}_{3}$ catalyst was tested at conversion of propane-propylene mixture. Aromatic hydrocarbons, $\mathrm{C}_{1}-\mathrm{C}_{4}$ hydrocarbons were found in the reaction products during conversion propane-propylene mixture over this catalyst (Table 5). A significant increase in the yield of aromatic hydrocarbons is observed at conversion of propane-propylene mixture, particularly at low temperatures $\left(450-550{ }^{\circ} \mathrm{C}\right)$ in comparison when using a propane-butane mixture under similar conditions. Thus, when processing propane-butane mixture on the $\mathrm{Zn}-\mathrm{La}-\mathrm{Fe}-\mathrm{ZSM}-\mathrm{Al}_{2} \mathrm{O}_{3}$ at $450^{\circ} \mathrm{C}$ the yield of aromatic hydrocarbons was $28.4 \%$, while the processing under the same conditions a propanepropylene mixture the yield of aromatic hydrocarbons increased to $35.2 \%$. With increase of reaction temperature in the range of $450-500{ }^{\circ} \mathrm{C}$ the yield of aromatic hydrocarbons increases from $35.2 \%$ $\left(450{ }^{\circ} \mathrm{C}\right)$ to $38.4 \%\left(550{ }^{\circ} \mathrm{C}\right)$, but with the further growth of temperature their amount decreases to $33.9 \%\left(600^{\circ} \mathrm{C}\right)$. The degree of conversion is $61.8 \%$ at $450^{\circ} \mathrm{C}$ and it reaches $100 \%$ with temperature growth to $600^{\circ} \mathrm{C}$.

Comparison of the results obtained during processing of propane-butane and propanepropylene mixtures over the $\mathrm{Zn}$-La-Fe-ZSM-Al ${ }_{2} \mathrm{O}_{3}$ catalyst shows that the composition of the feedstock practically does not affect the conversion. The amount of aromatic hydrocarbons formed is higher when using a propane-propylene mixture. At a temperature of $550^{\circ} \mathrm{C}$, the yield of the liquid products during processing of the propane-propylene mixture is $38.4 \%$ and the propane-butane yield is $34.6 \%$ (Table 3 and 5).

Physical and chemical characteristics of the synthesized catalysts were studied. The specific surface area and porosity of the catalysts have been measured by BET method on low-temperature adsorption of nitrogen. The specific surface of catalysts ranges within $283.5-310.7 \mathrm{~m}^{2} / \mathrm{g}$ and pores dominate with $d=1.5-3.0 \mathrm{~nm}$ (Table 6).
The acid-base characteristics of the catalysts are also essential for the conversion process of light hydrocarbons. The acidic characteristics of catalysts were studied by temperature-programmed desorption of ammonia. From the data provided in Table 7 it is seen that ammonia on the surface of the catalyst $\mathrm{Zn}$-La-Fe-ZSM-Al $\mathrm{O}_{3}$ is non-uniform and adsorbed in three forms. The weakly bound ammonia is desorbed from $t_{\max }=115^{\circ} \mathrm{C}$, tightly bound from $\mathrm{t}_{\mathrm{des}}=320^{\circ} \mathrm{C}$ and more tightly bound ammonia is desorbed at $\mathrm{t}_{\max }=470{ }^{\circ} \mathrm{C}$. Their quantity is equal to $22.60 ; 7.80$ and $4.80 \times 10^{-4} \mathrm{~mole} / \mathrm{g}$ of catalyst. The total content of acidic sites is equal to $35.20 \times 10^{-4}$ mole/g of catalyst.

Introduction of cobalt into the composition of the catalyst changes its acidic properties. The maximum desorption of weakly bound and strongly bound forms of ammonia in the Zn-La-Co-ZSM$\mathrm{Al}_{2} \mathrm{O}_{3}$ shifted to the area of higher temperatures from 115 to $152{ }^{\circ} \mathrm{C}$ and from 470 to $480^{\circ} \mathrm{C}$, where as the maximum desorption of ammonia with an average binding energy is shifted to the area of lower temperatures till $310^{\circ} \mathrm{C}$. However, their content changes slightly - $23.70,8.80$ and $4.00 \times 10^{-4} \mathrm{~mol} / \mathrm{g}$ of catalyst, respectively. The total amount of acidic sites is equal to $36.50 \times 10^{-4} \mathrm{~mole} / \mathrm{g}$ of catalyst.

Unlike the catalyst $\mathrm{Zn}$-La-Co-ZSM-Al $\mathrm{O}_{3}$ and Zn-La-Fe-ZSM-Al $\mathrm{O}_{3}$ for the Zn-La- Zr-ZSM$\mathrm{Al}_{2} \mathrm{O}_{3}$ is characteristic presence of more strong acid centers. At a temperature of desorption of $490^{\circ} \mathrm{C}$, the amount of stripped ammonia makes $9,4.10^{-4} \mathrm{~mol} / \mathrm{g}$ of the catalyst (Table 7).

\section{CONCLUSION}

The results shows that the catalyst $\mathrm{Zn}$-La$\mathrm{Zr}$-ZSM-Al $\mathrm{O}_{3}$ has low catalytic activity during the processing of the propane-butane fraction compared to Zn-La-Co-ZSM-Al $\mathrm{O}_{3}$ and Zn-La-Fe-ZSM-Al $\mathrm{O}_{3}$. The replacement of the modifying iron additive with cobalt results in an increase in the activity of the catalyst. The maximum activity is exhibited by the catalyst $\mathrm{Zn}$-La-Co-ZSM-Al $\mathrm{O}_{3}$, the conversion is $92.6 \%\left(500{ }^{\circ} \mathrm{C}\right)$. Under equal conditions, the highest yield of aromatic compounds and selectivity are observed on catalyst $\mathrm{Zn}-\mathrm{La}-\mathrm{Fe}-\mathrm{ZSM}-\mathrm{Al}_{2} \mathrm{O}_{3}$ : respectively $34.6 \%$ and $39.2 \%$. 
The structure and composition of the products formed during the processing of propanebutane propane-propylene mixtures indicate that modified zeolite-containing catalysts have polyfunctional properties. Several zeolite-containing $\mathrm{Zn}$-La-Zr-ZSM-Al $\mathrm{O}_{3}, \mathrm{Zn}$-La-Co-ZSM- $\mathrm{Al}_{2} \mathrm{O}_{3}$ and $\mathrm{Zn}$ La-Fe-ZSM- $\mathrm{Al}_{2} \mathrm{O}_{3}$ catalysts simultaneously and in parallel proceed with cracking, dehydrogenation, oligomerization, dehydrocyclization, alkylation. Cracking and dehydrogenation of the starting hydrocabons occur with the formation of intermediate activated complexes with a reduced content of carbon atoms and adsorbed olefinic structures. In the future, depending on the nature of the active center of the catalyst, various transformation directions develop with the participation of intermediate activated

\section{ACKNOWLEDGMENTS}

The authors wish to thank the Ministry of Education and Science of the Republic of Kazakhstan for sponsoring this research on the topics: «New technology for production of olefin and aromatic hydrocarbons from associated sulfur-containing and liquefied petroleum gas» and «Integrated waste-free catalytic processing of heavy oil into motor fuels and aromatics compounds».

\section{REFERENCES}

1. LIU Ru-ling, ZHU Hua-ging, WU Zhi-wei, QIN Zhang-feng., J. of Fuel Chem. and Techn., 2015, 43, 961-969.

2. Shets V.F., Sapunov V.N., Kozlovskii R.A., Staroverov D.V., Gartman T.N., Petroleum Chemistry, 2015, 55 (8) , 632-639.

3. Shiryazdanov R.R., Rakhimov M.N., Mansurov I.S., Petroleum Chemistry, 2010, 1 32-42.

4. Choudhary T.V., Kinage A., Banerjee S., Choudhary V.R., J. of Mol. Catal. A: Chemical, 2006, 246, 79-84.

5. Solymosi F., Zzechenyi A., Applied Catalysis A: General, 2004, 278, 111-121.

6. Dergachev A.A., Lapidus A.L., Russian Chemical Journal, 2008, 12, 15-22 (in Russ.).

7. Lubango M., Scurrell M.S., Applied Catalysis A: General, 2002, 235, 265-272.

8. Tuktin B.T., Zakumbayeva G.D., Smagulov R., Toktabayeva N.F., J.of refining and petrochem., 2008, 6, 35-43 (in Russ.).

9. Bulkatov A.N., J. oil processing and petrochem., 2008, 10, 30-38 (in Russ.).

10. Akhmetov A.F., Karatun O.N., J. of Chem. and Techn. of Fuels and Oils., 2001, 5, 35-41 (in Russ.).

11. Dedov A.G., Moiseyev I.I., Loktev A.S., Kuznetsov N.T., Ketsko V.A., Parkhomenko K.V., J. Chem. and Techn. of Fuels and Oils, 2007, 2, 35-42 (in Russ.).

12. Rasulov S.R., Mustafayeva G.R., Makhmudova L.A., J. of refining and petrochem. 2012, 2 ,36-43 (in Russ.).

13. Mustafayeva G.R., Salimova N.A., Rasulov S.R., J. of refining and petrochem., 2012, 5, 36- 42 (in Russ.).

14. Yushchenko V.V., Zakharov A.N., Romanovsky B.V., Kinetics and catalysis, 1986, 27 (2), 474-478. 